University of Nebraska - Lincoln

DigitalCommons@University of Nebraska - Lincoln

Reactions of thiocarbamate, triazine and urea herbicides, RDX and benzenes on EPA Contaminant Candidate List with ozone and with hydroxyl radicals

Wei R. Chen

University of California - Los Angeles, rwei2005@yahoo.com

Changlong Wu

Duke University

Michael S. Elovitz

U.S. EPA

Karl G. Linden

Duke University

I. H. Suffet

University of California - Los Angeles, msuffet@ucla.edu

Follow this and additional works at: https://digitalcommons.unl.edu/usepapapers

Chen, Wei R.; Wu, Changlong; Elovitz, Michael S.; Linden, Karl G.; and Suffet, I. H., "Reactions of thiocarbamate, triazine and urea herbicides, RDX and benzenes on EPA Contaminant Candidate List with ozone and with hydroxyl radicals" (2008). U.S. Environmental Protection Agency Papers. 161.

https://digitalcommons.unl.edu/usepapapers/161

This Article is brought to you for free and open access by the U.S. Environmental Protection Agency at DigitalCommons@University of Nebraska - Lincoln. It has been accepted for inclusion in U.S. Environmental Protection Agency Papers by an authorized administrator of DigitalCommons@University of Nebraska - Lincoln. 


\title{
Reactions of thiocarbamate, triazine and urea herbicides, RDX and benzenes on EPA Contaminant Candidate List with ozone and with hydroxyl radicals
}

\author{
Wei R. Chen ${ }^{a, *}$, Changlong Wu ${ }^{b}$, Michael S. Elovitz ${ }^{c}$, Karl G. Linden ${ }^{b}$, I.H. (Mel) Suffet ${ }^{a, d, *}$ \\ ${ }^{a}$ Department of Environmental Health Sciences, University of California at Los Angeles, Los Angeles, CA 90095, USA \\ ${ }^{b}$ Department of Civil and Environmental Engineering, Duke University, Durham, NC 27708, USA \\ ${ }^{\mathrm{c}}$ Treatment Technology and Evaluation Branch, Water Supply \& Water Resources Division, US EPA, Cincinnati, OH 45268, USA

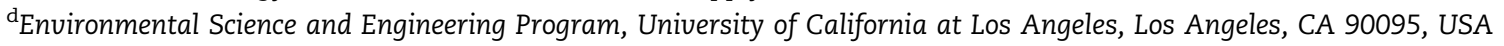

\section{A R T I C L E I N F O}

\section{Article history:}

Received 30 January 2007

Received in revised form

17 July 2007

Accepted 21 July 2007

Available online 29 July 2007

Keywords:

Rate constants

Direct ozone reactions

Indirect $\mathrm{OH}$ radical reactions

Ozonation

Ozone/hydrogen peroxide advanced

oxidation process

Contaminant Candidate List (CCL)

\begin{abstract}
A B S T R A C T
Second-order rate constants of the direct ozone reactions $\left(k_{\mathrm{O}_{3}, \mathrm{M}}\right)$ and the indirect OH radical reactions $\left(k_{\mathrm{OH}, \mathrm{M}}\right)$ for nine chemicals on the US EPA's Drinking Water Contaminant Candidate List (CCL) were studied during the ozonation and ozone/hydrogen peroxide advanced oxidation process $\left(\mathrm{O}_{3} / \mathrm{H}_{2} \mathrm{O}_{2}\right.$ AOP) using batch reactors. Except for the thiocarbamate herbicides (molinate and EPTC), all other CCL chemicals (linuron, diuron, prometon, $\mathrm{RDX}, 2$,4-dinitrotoluene, 2,6-dinitrotoluene and nitrobenzene) show low reactivity toward ozone. The general magnitude of ozone reactivity of the CCL chemicals can be explained by their structures and the electrophilic nature of ozone reactions. The CCL chemicals (except $\mathrm{RDX}$ ) are highly reactive toward $\mathrm{OH}$ radicals as demonstrated by their high $k_{\mathrm{OH}, \mathrm{M}}$ values. Ozonation at low $\mathrm{pH}$, which involves mainly the direct ozone reaction, is only efficient for the removal of the thiocarbamates. Ozonation at high $\mathrm{pH}$ and $\mathrm{O}_{3} / \mathrm{H}_{2} \mathrm{O}_{2}$ AOP will be highly efficient for the treatment of all chemicals in this study except RDX, which shows the lowest $\mathrm{OH}$ radical reactivity. Removal of a contaminant does not mean complete mineralization and reaction byproducts may be a problem if they are recalcitrant and are likely to cause health concerns.
\end{abstract}

(c) 2007 Elsevier Ltd. All rights reserved.

\section{Introduction}

The ozonation and ozone/hydrogen peroxide advanced oxidation process $\left(\mathrm{O}_{3} / \mathrm{H}_{2} \mathrm{O}_{2} \mathrm{AOP}\right)$ are recognized to be effective treatment processes to achieve degradation of contaminants in drinking water. The knowledge of chemical reaction kinetics is essential for predicting oxidation efficiencies of pollutants in these processes. During ozonation and $\mathrm{O}_{3} / \mathrm{H}_{2} \mathrm{O}_{2}$ AOP, a pollutant $(\mathrm{M})$ reacts both with $\mathrm{O}_{3}$ (the direct reactions) and $\mathrm{OH}$ radicals (the indirect reactions) through second-order kinetics. Prediction of the extent of degradation through these two pathways relies on knowing the intrinsic second-order rate constants for reactions of the pollutant with ozone $\left(k_{\mathrm{O}_{3}, \mathrm{M}}\right)$ and $\mathrm{OH}$ radicals $\left(k_{\mathrm{OH}, \mathrm{M}}\right)$. Although a large amount of kinetic data are available on the reaction rate constants of $\mathrm{OH}$ radicals and ozone with chemicals in aqueous solutions (Buxton et al., 1988), there is still a dearth of data especially for the emerging pollutants such as those on the US EPA's Drinking Water Contaminant Candidate List (CCL) (US EPA, 1998).

The objectives of the research were to determine the direct and indirect rate constants $\left(k_{\mathrm{O}_{3}, \mathrm{M}}\right.$ and $\left.k_{\mathrm{OH}, \mathrm{M}}\right)$ and the treatability for nine chemicals on the CCL by ozonation and the $\mathrm{O}_{3} / \mathrm{H}_{2} \mathrm{O}_{2}$ AOP. The pollutants studied include thiocarbamate,

\footnotetext{
*Corresponding authors. Tel.: +13102068230; fax: +13102063358.

E-mail addresses: rwei2005@yahoo.com (W.R. Chen), msuffet@ucla.edu (I.H. (Mel) Suffet).
} 0043-1354/\$ - see front matter (c) 2007 Elsevier Ltd. All rights reserved. doi:10.1016/j.watres.2007.07.037 
triazine and urea herbicides, RDX and substituted benzene compounds. Results were compared with literature data and a parallel study using UV/ $\mathrm{H}_{2} \mathrm{O}_{2}$ AOP (Shemer et al., 2006). The reactivity of the chemicals was correlated to their structures and reaction mechanisms.

\section{Methods}

\subsection{Reagents}

Most chemicals (>99\% purity) were purchased from Chem Service Inc. (West Chester, PA, USA). RDX was from AccuStandard Inc. (CT, USA) sold as solution in acetonitrile (ACN). All chemicals were used as received without further purification. Stock solutions of the CCL chemicals were prepared in dichloromethane (DCM), except for RDX which was in ACN. Aqueous reaction solutions were prepared by dispensing an appropriate amount of the stock solution into a dry flask, and then blowing off the solvent by a gentle flow of nitrogen gas before the phosphate-buffered water was added. Reaction solutions were stirred overnight for complete chemical dissolution. All other stock solutions were prepared in Milli-Q nanopure water.

Aqueous ozone stock solutions were prepared by continuously bubbling ozone produced by an oxygen-feed (oxygen $>99 \%$ ) ozonator (OSMONICS OREC ${ }^{\mathrm{TM}}$ V Series, Phoenix, AZ, USA) into Milli-Q water chilled in an ice-water bath (Bader and Hoigné, 1981). The concentration of ozone stock solution was about $35 \mathrm{mgL}^{-1}$. $\mathrm{pH}$ of all experiments were adjusted by adding orthophosphate buffers $\left(\mathrm{H}_{3} \mathrm{PO}_{4} / \mathrm{KH}_{2} \mathrm{PO}_{4} / \mathrm{Na}_{2} \mathrm{HPO}_{4}\right)$ so that the total phosphate concentration in the final solution was $0.02 \mathrm{M}$.

\subsection{Experiments}

All experiments were performed in $\mathrm{pH}$-buffered Milli-Q nanopure water at room temperature $\left(22^{\circ} \mathrm{C}\right)$. Experimental setups and procedures are similar to those described in Chen et al. (2006).

The direct rate constants of diuron, linuron and RDX with ozone $\left(k_{\mathrm{O}_{3}, \mathrm{M}}\right)$ were measured in a 1-L dispenser using solute consumption method under pseudo-first-order conditions. Initial concentrations of the CCL chemicals were about $0.5-1 \mu \mathrm{M}$, and the applied ozone doses ranged from 1.8 to $4.4 \mathrm{ppm}(37.5-91.7 \mu \mathrm{M})$. Hence, the ozone concentrations were in an approximate range of $37 \times$ to $183 \times$ excess. Furthermore, experiments were performed under acidic conditions ( $\mathrm{pH}$ 2.4) and with $10 \mathrm{mM}$ tertiary butanol to minimize ozone decomposition and any $\mathrm{OH}$ radical reactions with the CCL chemicals. The reaction conditions were such that the ozone concentration remained relatively constant (usually $\leqslant 8 \%$ decrease). The rate constants for the direct reaction were determined by monitoring chemical decay over time according to the following equation:

$\ln \left(\frac{[\mathrm{M}]_{\mathrm{t}}}{[\mathrm{M}]_{\mathrm{O}}}\right)=-k_{\mathrm{O}_{3}, \mathrm{M}}\left[\mathrm{O}_{3}\right] \mathrm{t}$.

The indirect rate constants of chemicals with $\mathrm{OH}$ radicals $\left(k_{\mathrm{OH}, \mathrm{M}}\right)$ were determined by competition kinetics method.
Hydroxyl radicals were produced by using either ozonation at pH 8.2 (for ureas and RDX) or ozone combined with $\mathrm{H}_{2} \mathrm{O}_{2}$ at $\mathrm{pH} 7.2$ (for the other CCL chemicals). In the ozonation experiments, an overall reaction rate constant $(k)$ was first determined by monitoring chemical decay over ozone exposure $\left(\int\left[\mathrm{O}_{3}\right] \mathrm{dt}\right)$ using Eq. (2). Ozone exposure can be calculated from the time kinetics of ozone during reaction. During the ozonation experiments, both direct and indirect reactions are taking place and the overall rate constants can be expressed by Eq. (3). $R_{c t}$, which is defined as the ratio between $\mathrm{OH}$ radical exposure and ozone exposure ( $=\int[\mathrm{OH}] \mathrm{dt} / \int\left[\mathrm{O}_{3}\right] \mathrm{dt}$ ), is usually a constant value for a specific reaction system and can be viewed as the concentration ratio between $\mathrm{OH}$ radicals and $\mathrm{O}_{3}$ (Elovitz and von Gunten, 1999). $R_{\mathrm{ct}}$ in an ozonation process was calculated by applying Eqs. (2) and (3) to a chemical with known $k_{\mathrm{OH}, \mathrm{M}}$ and $k_{\mathrm{O}_{3}, \mathrm{M}}$ values. With known $R_{\mathrm{ct},} k$ and $k_{\mathrm{O}_{3}, \mathrm{M}}$ values (determined above), the $k_{\mathrm{OH}, \mathrm{M}}$ of CCL can be obtained through Eq. (3).

$\ln \left(\frac{[\mathrm{M}]_{\mathrm{t}}}{[\mathrm{M}]_{\mathrm{o}}}\right)=-k \int_{0}^{\mathrm{t}}\left[\mathrm{O}_{3}\right] \mathrm{dt}$,

$k=k_{\mathrm{OH}, \mathrm{M}} R_{\mathrm{ct}}+k_{\mathrm{O}_{3}, \mathrm{M}}$

In the $\mathrm{O}_{3} / \mathrm{H}_{2} \mathrm{O}_{2}$ experiments, the relative decay rate of a CCL chemical (M) to a reference compound (R) can be expressed as follows by applying Eqs. (2) and (3) to $\mathrm{M}$ and R:

$\ln \left(\frac{[\mathrm{M}]_{\mathrm{t}}}{[\mathrm{M}]_{\mathrm{o}}}\right) / \ln \left(\frac{[\mathrm{R}]_{\mathrm{t}}}{[\mathrm{R}]_{\mathrm{o}}}\right)$

$=\left(k_{\mathrm{OH}, \mathrm{M}} R_{\mathrm{ct}}+k_{\mathrm{O}_{3}, \mathrm{M}}\right) /\left(k_{\mathrm{OH}, \mathrm{R}} R_{\mathrm{ct}}+k_{\mathrm{O}_{3}, \mathrm{R}}\right)$.

When $k_{\mathrm{O}_{3}}$ of the reference and the CCL chemical are very small, the above equation can be simplified as

$k_{\mathrm{OH}, \mathrm{M}}=k_{\mathrm{OH}, \mathrm{R}} \times \ln \left(\frac{[\mathrm{M}]_{\mathrm{t}}}{[\mathrm{M}]_{\mathrm{O}}}\right) / \ln \left(\frac{[\mathrm{R}]_{\mathrm{t}}}{[\mathrm{R}]_{\mathrm{o}}}\right)$.

Eq. (5) was applied for the calculation of $k_{\mathrm{OH}, \mathrm{M}}$. The initial concentrations of CCL chemicals were about $2 \mu \mathrm{M}$ and the applied $\mathrm{H}_{2} \mathrm{O}_{2}$ concentration was $0.1 \mathrm{mM}$. Six to eight ozone doses ranging from 0.5 to $5 \mathrm{mgL}^{-1}$ (ca. $0.01-0.1 \mathrm{mM}$ ) were applied during the $\mathrm{O}_{3} / \mathrm{H}_{2} \mathrm{O}_{2}$ experiments to create $\mathrm{H}_{2} \mathrm{O}_{2} / \mathrm{O}_{3}$ molar ratios from 10 to 1 .

\subsection{Analytical methods}

Dissolved ozone was measured using the indigo method (Bader and Hoigné, 1981). CCL chemical concentrations were monitored by routine HPLC-UV analyses. Samples $(50 \mu l$ per injection) were directly injected into a Varian Pro Star HPLC (Varian, Inc., Palo Alto, CA, USA). A C18 column $(7.5 \times 150 \mathrm{~mm})$ was used for separation and ACN/water was used as the eluting solvent at a flow rate of $1 \mathrm{~mL} \mathrm{~min}^{-1}$. Varian Model 330 UV detector was used for measuring the absorbance at different wavelengths shown in Table 1 . The method detection limit is about $5 \mathrm{nM}$.

\section{Results and discussion}

Results of $k_{\mathrm{O}_{3}, \mathrm{M}}$ and $k_{\mathrm{OH}, \mathrm{M}}$ for the CCL chemicals (see Table 1 for structures) are shown in Tables 2 and 3, respectively. Example calculations of $k_{\mathrm{O}_{3}, \mathrm{M}}$ and $k_{\mathrm{OH}, \mathrm{M}}$ are shown in 
Table 3 - Rate constants for indirect reactions $\left(k_{\mathrm{OH}, \mathrm{M}}\left(\mathrm{M}^{-1} \mathrm{~s}^{-1}\right)\right)$ of the CCL chemicals with $\mathrm{OH}$ radicals

\begin{tabular}{|c|c|c|c|c|c|c|c|}
\hline \multirow[t]{2}{*}{ Groups } & \multirow[t]{2}{*}{$\begin{array}{l}\text { Chemical } \\
\text { names }\end{array}$} & \multirow[t]{2}{*}{$\mathrm{pH}^{\mathrm{a}}$} & \multicolumn{2}{|c|}{$\begin{array}{l}\text { Ozonation and } \mathrm{O}_{3} / \mathrm{H}_{2} \mathrm{O}_{2} \\
\qquad\left(22^{\circ} \mathrm{C}\right)\end{array}$} & \multicolumn{2}{|c|}{$\mathrm{UV} / \mathrm{H}_{2} \mathrm{O}_{2}\left(22^{\circ} \mathrm{C}\right)^{\mathrm{b}}$} & \multirow[t]{2}{*}{$\begin{array}{l}\text { Literature values } \\
\qquad\left(\times 10^{9}\right)\end{array}$} \\
\hline & & & $\begin{array}{c}k_{\mathrm{OH}, \mathrm{M}} \\
\left(\times 10^{9}\right)\end{array}$ & Ref. Comp. ${ }^{c}$ & $\begin{array}{c}k_{\mathrm{OH}, \mathrm{M}} \\
\left(\times 10^{9}\right)\end{array}$ & $\begin{array}{l}\text { Ref. } \\
\text { comp. }\end{array}$ & \\
\hline \multirow[t]{2}{*}{ Ureas } & Diuron & 8.2 & $7.66 \pm 0.39^{e}$ & BB & $7.5 \pm 0.23$ & Molinate & $4.6^{\mathrm{f}}$ \\
\hline & Linuron & 8.2 & $6.44 \pm 0.30$ & BB & $6.5 \pm 0.28$ & Molinate & $4.3^{\mathrm{f}}$ \\
\hline $\mathrm{RDX}$ & $\mathrm{RDX}$ & 8.2 & $0.25 \pm 0.008$ & BB & $(1.6 \pm 0.19)^{g}$ & NB & $0.34^{\mathrm{h}}$ \\
\hline \multirow[t]{2}{*}{ Triazine } & Prometon & 7.2 & 2.6 & 2,4-DNT & $2.5 \pm 0.01$ & Molinate & \\
\hline & & 7.2 & 2.53 & Molinate & & & \\
\hline \multirow[t]{3}{*}{ Thiocarbamates } & EPTC & 7.2 & $(13.2 \pm 0.5)^{g}$ & NB & & & \\
\hline & Molinate & 7.2 & $(12.4 \pm 0.2)^{\mathrm{g}}$ & $\begin{array}{l}\text { NB and } \\
\text { Prometon }\end{array}$ & $6.9 \pm 0.06$ & NB & $1.3^{\mathrm{i}}$ \\
\hline & & & & & & & $2.14^{j}$ \\
\hline \multirow{5}{*}{$\begin{array}{l}\text { Substituted } \\
\text { benzenes }\end{array}$} & Nitrobenzene & & & & & & $3.9^{\mathrm{i}}$ \\
\hline & & & & & & & $2.9^{\mathrm{k}}$ \\
\hline & 2,4-DNT & 7.2 & $1.26 \pm 0.02$ & NB & & & \\
\hline & 2,6-DNT & 7.2 & 0.921 & Prometon & & & $0.75^{\mathrm{k}}$ \\
\hline & & 7.2 & 0.996 & Molinate & & & \\
\hline 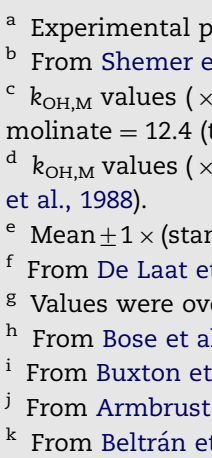 & $\begin{array}{l}\text { nditions. } \\
\text { (2006). } \\
\mathrm{M}^{-1} \mathrm{~s}^{-1} \text { ) of the re } \\
\text { tudy), prometor } \\
\mathrm{M}^{-1} \mathrm{~s}^{-1} \text { ) used for } \\
\text { error). Two exp } \\
\text { 1996) ( } 20^{\circ} \mathrm{C} \text {, ozo } \\
\text { imated (see text } \\
\text { 98a) (estimated } \\
\text { 1988) (molinate } \\
\text { 0) }\left(25^{\circ} \mathrm{C}, \mathrm{UV} / \mathrm{H}_{2} \mathrm{C}\right. \\
\text { 1998a) }\left(20^{\circ} \mathrm{C}, \mathrm{O}_{3}\right.\end{array}$ & $\begin{array}{l}\text { ence c } \\
2.6 \text { (th } \\
\text { refere } \\
\text { ments } \\
\text { ion at } \\
\text { expla } \\
\mathrm{n} \text { a pil } \\
\mathrm{JV} / \mathrm{H}_{2} \mathrm{C} \\
\mathrm{H} 7 \text { ). } \\
\mathrm{O}_{2}, \mathrm{pH}\end{array}$ & $\begin{array}{l}\text { apounds used } \\
\text { study) and nit } \\
\text { e compounds } \\
\text { re performed } \\
>9.5 \text { or } \mathrm{O}_{3} / \mathrm{H} \\
\text { tions). } \\
\text { study by } \mathrm{UV} / \\
\text { nitrobenzene }\end{array}$ & $\begin{array}{l}\text { : bromobenzen } \\
\text { enzene }(\mathrm{NB})= \\
\text { e: molinate }=6 \text {. } \\
\text { lere the standa } \\
\text { at } \mathrm{pH}>8.2 \text { ). } \\
\text { 2). } \\
\text { pulse radiolysi }\end{array}$ & $\begin{array}{l}\text { BB) }=5.3 \text { (Che } \\
\text { (Buxton et al. } \\
\text { shemer et al., } \\
\text { errors were re }\end{array}$ & $\begin{array}{l}\text { tel., 2006), } \\
\text { 988). } \\
\text { 06) and nitro } \\
\text { rted. }\end{array}$ & $\begin{array}{l}\mathrm{NT}=1.26 \text { (this study), } \\
\text { zene }(\mathrm{NB})=3.9 \text { (Buxton }\end{array}$ \\
\hline
\end{tabular}

a

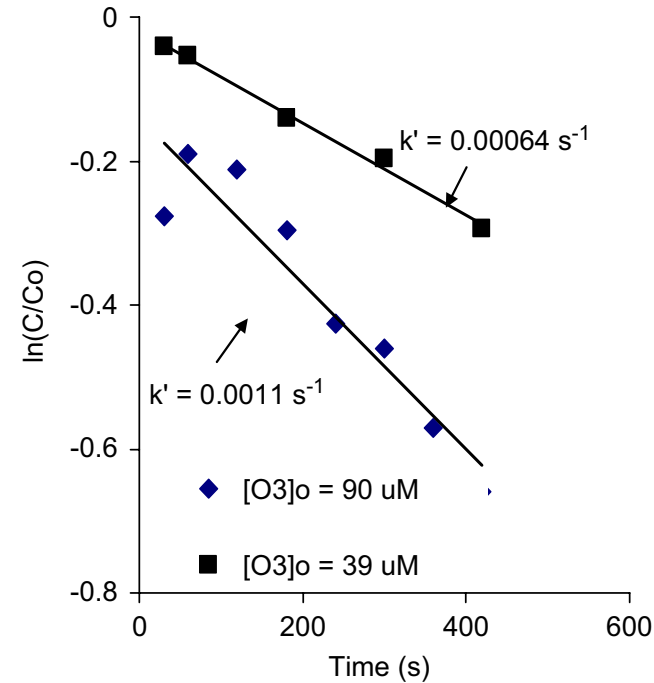

b

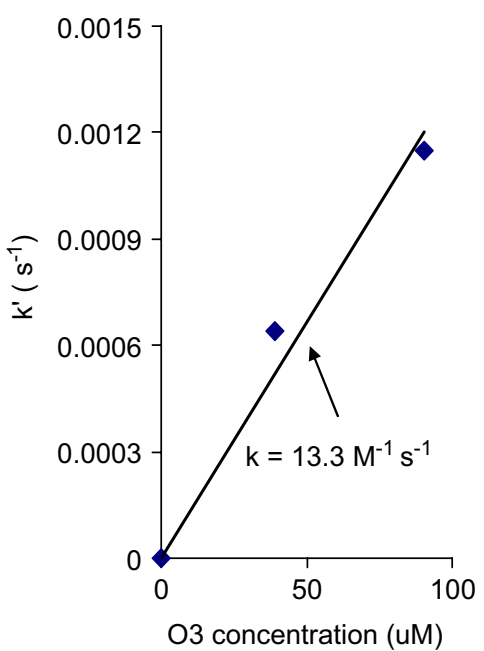

Fig. 1 - Determination of $k_{\mathrm{O}_{3}, \mathrm{M}}$ for diuron. (a) Change of $\ln \left(\mathrm{C} / \mathrm{C}_{0}\right)$ vs. time for diuron at different initial ozone concentrations. $\mathrm{pH}=2.4$; [diuron] $]_{0}=1.03$ and $2.18 \mu \mathrm{M}$. A pseudo-first-order decay rate $\left(k^{\prime}\right)$ is obtained. (b) Variation of $k^{\prime}$ with initial concentrations of ozone. $k^{\prime}=k_{\mathrm{O}_{3}, \mathrm{M}}\left[\mathrm{O}_{3}\right]_{0}$ (according to Eq. (1)). Second-order decay constant $k_{\mathrm{O}_{3}, \mathrm{M}}$ is the slope in (b). 


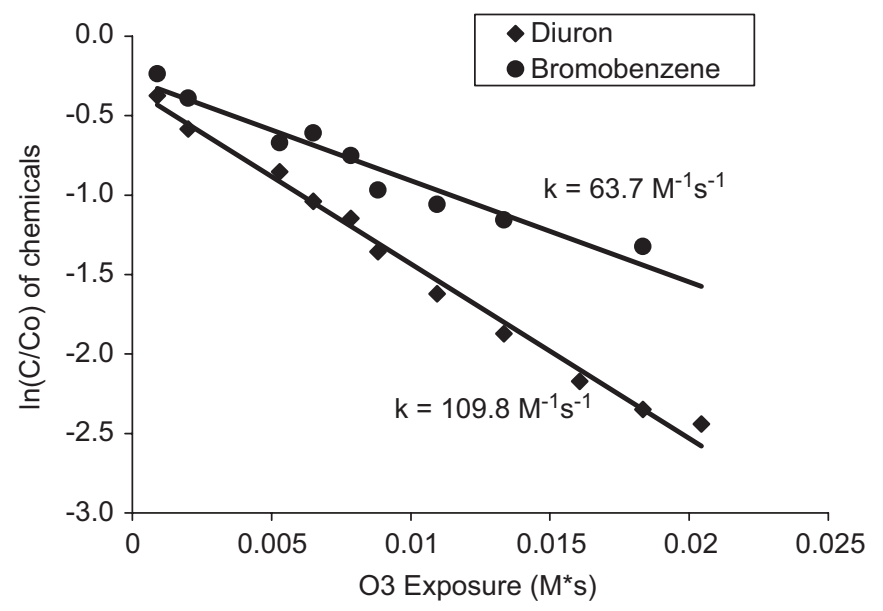

Fig. 2 - Determination of $k_{\mathrm{OH}, \mathrm{M}}$ by ozonation process at $\mathrm{pH}$ 8.2. [diuron] $0=0.86 \mu \mathrm{M}$, bromobenzene $(\mathrm{BB})=$ the reference compound, $[\mathrm{BB}]_{0}=0.36 \mu \mathrm{M},\left[\mathrm{O}_{3}\right]_{0}=33 \mu \mathrm{M}$. The overall second-order rate constants $(\mathrm{k})$ of the CCL chemical and the reference are the slopes in the figure. $R_{\mathrm{ct}}$ in the ozonation process is calculated to be $1.2 \times 10^{-8}$ by applying $k_{\mathrm{OH}, \mathrm{BB}}\left(5.3 \times 10^{9} \mathrm{M}^{-1} \mathrm{~s}^{-1}\right)$ and $k_{\mathrm{O}_{3}, \mathrm{BB}}\left(0.16 \mathrm{M}^{-1} \mathrm{~s}^{-1}\right)$ to $\mathrm{Eq}$. (3). $k_{\mathrm{OH}, \mathrm{M}}$ of diuron is calculated by applying the known $k$ and $R_{\mathrm{ct}}$ values to Eq. (3).

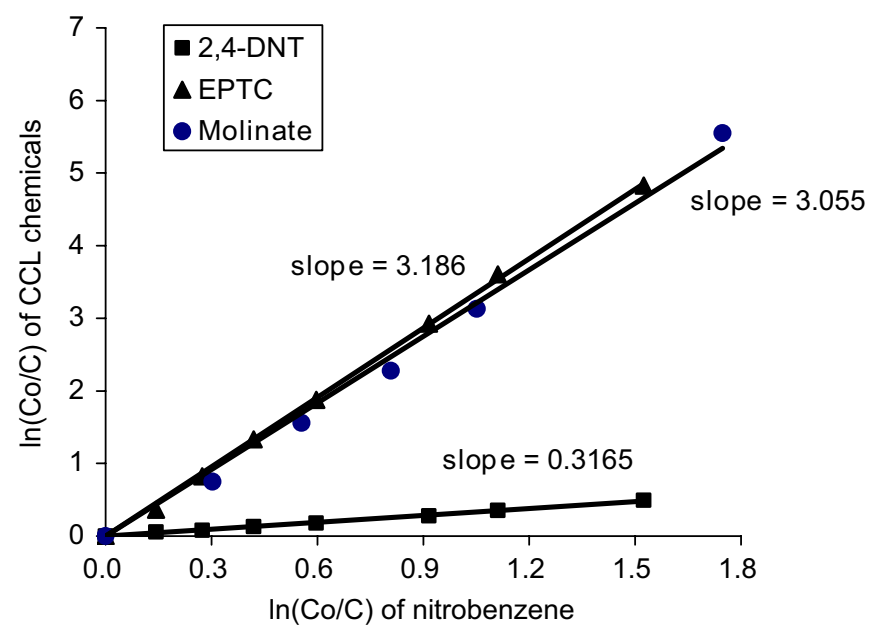

Fig. 3 - Determination of $k_{\mathrm{OH}, \mathrm{M}}$ for CCL chemicals using $\mathrm{O}_{3} / \mathrm{H}_{2} \mathrm{O}_{2}$ AOP at pH 7.2. [EPTC $]_{0}=2.3 \mu \mathrm{M},[2,4-\mathrm{DNT}]_{0}=1.84 \mu \mathrm{M}$, [nitrobenzene $]_{0}=2.0 \mu \mathrm{M},\left[\mathrm{H}_{2} \mathrm{O}_{2}\right]_{0}=0.1 \mathrm{mM},\left[\mathrm{O}_{3}\right]_{0}=0,0.5,1,1.5,2,3,4$ and $5 \mathrm{mg} \mathrm{L}^{-1}$ (or $0,10,21,31,42,62,83$ and $104 \mu \mathrm{M}$ ). Decay rates of CCL chemicals are plotted against the decay rate of the reference compound. $k_{\mathrm{OH}, \mathrm{M}}$ is calculated by multiplying $k_{\mathrm{OH}, \mathrm{M}}$ of the reference (nitrobenzene) and the slope obtained (see Eq. (5)).

kinetics method is sensitive to the $k_{\mathrm{O}_{3}, \mathrm{M}}$ values of the reference compounds used. Similar results by different methods usually suggest similar reaction mechanisms (sometimes it is an overall expression of several reaction channels in competition), and that the interferences (or drawbacks) in each method are negligible.

The $k_{\mathrm{OH}, \mathrm{M}}$ values of the ureas from this study are higher than those from De Laat et al. (1996), though the same method and similar reaction conditions were used. The differences may reflect differences in the experimental setups, sample handling, analytical methods used and machine performance. Sometimes it may also reflect differences in the balance among the different reaction channels in operation. The reaction rates measured following the disappearance of the starting material indicate how fast the starting material reacts but gives no indication about the possibility of the occurrence of several reaction channels in competition. Hence, the measured rate constants of a given compound with ozone or hydroxyl radicals are a combination of the rate constants of the individual reaction channels occurring in competition.

The $k_{\mathrm{OH}, \mathrm{M}}$ value of 2,6-DNT measured by competition kinetics method during $\mathrm{O}_{3} / \mathrm{H}_{2} \mathrm{O}_{2}$ is higher than that from Beltrán et al. (1998a) using absolute kinetics method by mass transfer principles. This is because our study used a higher $k_{\mathrm{OH}, \mathrm{NB}}$ value (see Table 3 ) as the reference. However, the $k_{\mathrm{OH}}$ ratios of $\mathrm{NB}$ and 2,6-DNT in both studies are similar (3.9 vs. 4.1), indicating results are comparable between the two studies.

The $k_{\mathrm{OH}, \mathrm{M}}$ results from this study and from a parallel study using $\mathrm{UV} / \mathrm{H}_{2} \mathrm{O}_{2}$ process (Shemer et al., 2006) should be more comparable since samples were handled in the same way and were analyzed on the same machine. However, many chemicals in this study (including molinate, the reference 
compound) undergo significant direct photolysis reactions (over the $\mathrm{OH}$ radical reaction) during the $\mathrm{UV} / \mathrm{H}_{2} \mathrm{O}_{2}$ process. Although a new method was established by Shemer et al. (2006) to account for the effect of direct photolysis, there is still uncertainty in the $k_{\mathrm{OH}, \mathrm{M}}$ values obtained in this way. In contrast, the ozonation and $\mathrm{O}_{3} / \mathrm{H}_{2} \mathrm{O}_{2}$ AOP used in this study are mostly $\mathrm{OH}$ radical-dominant processes. Except for the thiocarbamates, the $k_{\mathrm{O}_{3}, \mathrm{M}}$ values of the CCL chemicals studied (see Table 2) are so low that the interference of the direct reactions is negligible during the determination of $k_{\mathrm{OH}, \mathrm{M}}$. The matching $k_{\mathrm{OH}, \mathrm{M}}$ values of ureas by $\mathrm{UV} / \mathrm{H}_{2} \mathrm{O}_{2}$ and by ozonation, especially that of linuron whose direct photolysis pathway is significant $\left(k_{d}^{\prime}=1.25 \times 10^{-3} \mathrm{~cm}^{2} \mathrm{~mJ}^{-1}\right.$, Shemer et al., 2006), demonstrate that the new method by Shemer et al. (2006) is efficient in accounting for the effect of direct photolysis. However, for RDX $\left(k_{d}^{\prime}=4.7 \times 10^{-3} \mathrm{~cm}^{2} \mathrm{~mJ}^{-1}\right.$, Shemer et al., 2006), in which the direct photolysis is dominant over the $\mathrm{OH}$ radical pathway, the new method seems to be not sufficient. On the other hand, the $k_{\mathrm{OH}, \mathrm{M}}$ value of molinate by $\mathrm{O}_{3} / \mathrm{H}_{2} \mathrm{O}_{2}$ is not consistent with that by $\mathrm{UV} / \mathrm{H}_{2} \mathrm{O}_{2}$, which is probably due to interference from its significant direct $\mathrm{O}_{3}$ reactions. Prometon has very slow direct photolysis and direct $\mathrm{O}_{3}$ reactions, and the two methods $\left(\mathrm{UV} / \mathrm{H}_{2} \mathrm{O}_{2}\right.$ and $\left.\mathrm{O}_{3} / \mathrm{H}_{2} \mathrm{O}_{2}\right)$ agree well.

The use of $\mathrm{O}_{3} / \mathrm{H}_{2} \mathrm{O}_{2}$ AOP in the determination of $k_{\mathrm{OH}, \mathrm{M}}$ values of molinate and other chemicals with fast direct $\mathrm{O}_{3}$ reactions is therefore not recommended. Even if very high $\mathrm{pH}$ and $\mathrm{H}_{2} \mathrm{O}_{2}$ concentrations are applied, it is still uncertain if there are interferences from the direct $\mathrm{O}_{3}$ reactions. Literature has given three different $k_{\mathrm{OH}, \mathrm{M}}$ values of molinate (see Table 3 ) by using $\mathrm{UV} / \mathrm{H}_{2} \mathrm{O}_{2}$ method. Therefore, $k_{\mathrm{OH}, \mathrm{M}}$ value of molinate needs to be confirmed preferably by another method (e.g. pulse radiolysis).

The $k_{\mathrm{O}_{3}, \mathrm{M}}$ values of prometon, 2,4-DNT and 2,6-DNT were estimated by correlating them with compounds of similar structures and by the electrophilic natural of the direct $\mathrm{O}_{3}$ reactions. Similar rates can be derived if reactions take place at the same functional groups. Electron-releasing or withdrawing property of the adjacent groups can also significantly alter the reaction rates by making the reaction sites more or less electrophilic for $\mathrm{O}_{3}$ attacks. The $k_{\mathrm{O}_{3}, \mathrm{M}}$ values of molinate and EPTC were calculated by applying the $R_{\mathrm{ct}}$ concept (Elovitz and von Gunten, 1999). These estimates can provide the orders of magnitude of the reaction rates, which can be of value in many ways.

\subsection{Urea herbicides}

Both diuron and linuron show low reactivity toward ozone indicated by small $k_{\mathrm{O}_{3}, \mathrm{M}}$ values. The small rate constants indicate that ozonation at low $\mathrm{pH}$ will not be effective in degrading these compounds. Assuming that the reactivity of both compounds is due to $\mathrm{O}_{3}$ attack at the aromatic ring, the low reactivity can be explained as due to the two electronwithdrawing $\mathrm{Cl}$ groups on the benzene ring, which decrease the electron density of the ring and hence decrease the electrophilic attack by ozone. This is also supported by lower reaction rates of diuron and linuron (dichlorinated ureas) compared to their corresponding monochlorinated analoges (monouron and monolinuron) under more molecular (i.e. direct $\mathrm{O}_{3}$ reaction) conditions $\left(\mathrm{O}_{3} / \mathrm{H}_{2} \mathrm{O}_{2}, \mathrm{pH}\right.$ 5.6) (Tahmasseb et al., 2002). Under more radical (i.e. indirect reaction) conditions $\left(\mathrm{O}_{3} / \mathrm{H}_{2} \mathrm{O}_{2}, \mathrm{pH}\right.$ 7), the dichlorinated ureas react faster than their monochlorinated analoges (Tahmasseb et al., 2002). Diuron shows a much higher $\mathrm{O}_{3}$ reactivity (a five-fold difference) than linuron. It was also found by Tahmasseb et al. (2002) that $\mathrm{N}$-dimethylureas were more reactive than their $\mathrm{N}$-methyl, $\mathrm{N}$-methoxy counterparts at low $\mathrm{pH}$.

Unlike the rate of direct ozone reactions, the indirect radical reaction rate of diuron is only slightly higher than that of linuron. Product study (Tahmasseb et al., 2002) shows that the primary $\mathrm{OH}$ radical reaction for diuron is through $\mathrm{N}$-demethylation (to form mono $\mathrm{N}$-demethylated diuron) rather than by $\mathrm{OH}$ addition to the aromatic ring. With linuron, $\mathrm{N}$-demethylation accompanied by elimination of $\mathrm{N}$-methoxy group (to form 3,4-dichlorophenylurea) is a more important pathway. Both linuron and diuron have high $\mathrm{OH}$ radical reactivity (on the order of $10^{9}$ ), therefore they can be efficiently removed by processes that mainly involve $\mathrm{OH}$ radical reactions (e.g. $\mathrm{O}_{3} / \mathrm{H}_{2} \mathrm{O}_{2}, \mathrm{UV} / \mathrm{H}_{2} \mathrm{O}_{2}$ and ozonation at high $\mathrm{pH})$. Meijers et al. (1995) reported $98 \%$ and $89 \%$ removal for diuron and linuron, respectively, at $\mathrm{pH} 8.3$ with $\mathrm{O}_{3} / \mathrm{DOC}$ ratio of 1.0 using ozone bubbling column.

\section{2. $R D X$}

RDX shows low reactivity toward ozone and $\mathrm{OH}$ radicals as demonstrated by its low $k_{\mathrm{O}_{3}, \mathrm{M}}$ and $k_{\mathrm{OH}, \mathrm{M}}$ values. Its ring structure and the highly oxidized nitro groups are resistant to ozone and $\mathrm{OH}$ radical oxidation. Given the very low reactivity with ozone and $\mathrm{OH}$ radicals, $\mathrm{RDX}$ is not expected to be efficiently removed in an ozonation or $\mathrm{O}_{3} / \mathrm{H}_{2} \mathrm{O}_{2}$ operation. Bose et al. (1998a) reported that the $\mathrm{O}_{3} / \mathrm{H}_{2} \mathrm{O}_{2}$ process, using a $\mathrm{H}_{2} \mathrm{O}_{2} / \mathrm{O}_{3}$ ratio of $0.35 \mathrm{~g} / \mathrm{g}$, was effective at oxidizing $\mathrm{RDX}$ with a $t_{1 / 2}$ of $1.2 \mathrm{~min}$ (vs. $t_{1 / 2}$ of $115 \mathrm{~min}$ for ozone alone at pH 7.2). However, that experiment employed high ozone and $\mathrm{H}_{2} \mathrm{O}_{2}$ doses (e.g. $16 \mathrm{mg} \mathrm{L}^{-1} \mathrm{O}_{3}$ and $5.6 \mathrm{mgL}^{-1} \mathrm{H}_{2} \mathrm{O}_{2}$ to achieve $99 \%$ $\mathrm{RDX}$ removal). Under less aggressive AOP operation (e.g. $\mathrm{OH}$ radical CT for $90 \%$ removal of MIB), only a $7 \%$ removal of RDX could be expected. Worth noting, however, is the potential use of direct photolysis for RDX treatment because of its fast direct photolysis rate $\left(k^{\prime}{ }_{d}=4.7 \times 10^{-3} \mathrm{~cm}^{2} \mathrm{~mJ}^{-1}\right.$, Shemer et al., 2006). Product study shows that hydroxyl radicals would probably attack the amine nitrogen of RDX; hydroxyl radicals would also promote the cleavage of the heterocyclic ring during AOPs (Bose et al., 1998b).

\subsection{Triazine herbicide}

Prometon is also expected to have low reactivity toward ozone. The triazine ring is very resistant to oxidation, and hence reactivity of prometon toward ozone will likely be dictated by side chains. Barletta et al. (2003) found that $\mathrm{N}$-dealkylated triazine is the major reaction product of<smiles>CC(C)Nc1nc(Cl)nc(NC(C)C)n1</smiles>

ably by electrophilic attack of ozone at one of the amine 
nitrogens. Prometon is very likely to react with ozone in a similar fashion. Therefore, the $\mathrm{O}_{3}$ reaction rate of prometon is expected to be close to that of propazine: $k_{\mathrm{O}_{3}, \mathrm{M}}=1.53 \mathrm{M}^{-1} \mathrm{~s}^{-1}$ at pH 3 and $25^{\circ} \mathrm{C}$ (Barletta et al., 2003). The $k_{O_{3}, \mathrm{M}}$ of propazine was measured under conditions in which both the unprotonated and the protonated forms of triazine were present (Almost no reactions were observed at $\mathrm{pH} 0$ where only the protonated form existed in solution.) (Barletta et al., 2003). Therefore, the $\mathrm{O}_{3}$ reactivity of prometon under neutral and basic solutions, where only the unprotonated form exist is expected to be higher. Xiong and Graham (1992) has reported $k_{\mathrm{O}_{3}, \mathrm{M}}$ of $12.2 \mathrm{M}^{-1} \mathrm{~s}^{-1}$ (at $20^{\circ} \mathrm{C}$ ) at $\mathrm{pH} 7.5$ for atrazine . The $k_{\mathrm{O}_{3}, \mathrm{M}}$ of unprotonated prometon will be lower than that of atrazine at similar conditions because: (1) ozone reacts faster with atrazine than with propazine (Barletta et al., 2003); and (2) $k_{\mathrm{O}_{3}, \mathrm{M}}$ of atrazine was likely overestimated due to radical reactions occurring at $\mathrm{pH} 7.5$ (Xiong and Graham, 1992).

Despite of the low ozone reactivity, prometon shows reasonable reactivity toward $\mathrm{OH}$ radicals and thus can be efficiently degraded by the $\mathrm{OH}$ radical dominated treatment processes. Byproducts of the $\mathrm{TiO}_{2}$-mediated photooxidation of prometon show that prometon was oxidized by $\mathrm{OH}$ radicals primarily through $\mathrm{N}$-deisopropylation and may be also through the substitution of the methoxy group by a hydroxyl group (Borio et al., 1998). These pathways are very much comparable to that of atrazine during $\mathrm{O}_{3} / \mathrm{H}_{2} \mathrm{O}$ AOP (Nélieu et al., 2000); the $k_{\mathrm{OH}, \mathrm{M}}$ value of prometon $\left(2.6 \times 10^{9} \mathrm{M}^{-1} \mathrm{~s}^{-1}\right)$ is also similar to that of atrazine $\left(3 \times 10^{9} \mathrm{M}^{-1} \mathrm{~s}^{-1}\right)$ (Acero et al., 2000).

\subsection{Thiocarbamate herbicides}

The $k_{\mathrm{OH}, \mathrm{M}}$ values of molinate and EPTC measured by $\mathrm{O}_{3} / \mathrm{H}_{2} \mathrm{O}_{2}$ are considerably higher than those measured by $\mathrm{UV} / \mathrm{H}_{2} \mathrm{O}_{2}$ in the literature (see Table 3). The greater value is likely due to the negligence of the fast direct ozone reactions of the molinate in the calculation of $k_{\mathrm{OH}, \mathrm{M}}$ using conventional competition kinetics method where $k_{\mathrm{O}_{3}, \mathrm{M}}$ of both the reference and the substrate compound are ignored (see Eq. (5)). This likely occurred in the measurement of $k_{\mathrm{OH}, \mathrm{M}}$ value for EPTC as well. The nucleophilic $S$ atom of both thiocarbamates is highly reactive toward $\mathrm{O}_{3}$, and the $k_{\mathrm{O}_{3}, \mathrm{M}}$ for simple alkyl sulfides (-RSR'(or $\mathrm{H})$-) are usually around or greater than $10^{4}-10^{5} \mathrm{M}^{-1} \mathrm{~s}^{-1}$ (Yao and Haag, 1991; Hoigné and Bader, 1983). However, the $k_{\mathrm{O}_{3}, \mathrm{M}}$ of molinate and EPTC are expected to be lower because the lone pair of $\mathrm{S}$ electrons can be conjugated with the adjacent $\mathrm{C}=\mathrm{O}$ double bond and thus makes it less available for reaction. Furthermore, the $\mathrm{C}=\mathrm{O}$ group, which is electron withdrawing, can also decrease the electron density of $\mathrm{S}$ to make it less electrophilic (i.e. less $\mathrm{O}_{3}$ reactive).

It is interesting to observe that although the $k_{\mathrm{OH}, \mathrm{M}}$ of molinate measured by $\mathrm{O}_{3} / \mathrm{H}_{2} \mathrm{O}_{2}\left(1.2 \times 10^{10} \mathrm{M}^{-1} \mathrm{~s}^{-1}\right)$ is potentially as much as $10 \times$ too large, the use of this value in Eq. (5) for molinate as a reference compound still gave consistent results for measuring $k_{\mathrm{OH}, \mathrm{M}}$ of prometon and 2,6-DNT in $\mathrm{O}_{3} / \mathrm{H}_{2} \mathrm{O}_{2}$ experiments with other reference compounds (see Table 3). This is because nitrobenzene, which has low $\mathrm{O}_{3}$ reactivity $\left(\mathrm{k}_{\mathrm{O}_{3}, \mathrm{M}}\right.$ can be ignored in calculations), was used as a reference compound for measuring $k_{\mathrm{OH}, \text { Molinate }}$ Therefore, $k_{\mathrm{OH}, \mathrm{M}}$ of prometon and 2,6-DNT (both with low $\mathrm{O}_{3}$ reactivity) can be calculated as if nitrobenzene was used as their reference compound by further multiplying the slope of molinate in Fig. 3. However, we will not obtain correct $k_{\mathrm{OH}, \mathrm{M}}$ values for an $\mathrm{O}_{3}$ reactive chemical if molinate is used as the reference compound in the $\mathrm{O}_{3} / \mathrm{H}_{2} \mathrm{O}_{2}$ experiments using competition kinetics method. Furthermore, if an alternative $k_{\mathrm{OH} \text {,Molinate }}$ value (e.g. one from the literature) was used in the calculation, we would obtain wrong $k_{\mathrm{OH}, \mathrm{M}}$ values for prometon and 2,6-DNT. Therefore, special caution needs to be given to compounds with high ozone reactivity (either as reference or as substrate) when $k_{\mathrm{OH}, \mathrm{M}}$ is determined using Eq. (5).

If $k_{\mathrm{O}_{3} \text {,Molinate }}$ is not neglected in the calculation of $k_{\mathrm{OH}, \mathrm{Molinate}}$ (with nitrobenzene (NB) as the reference compound), the relationship between the true $k^{\prime}$ OH,Molinate value and the overestimated value (we name it $k_{\mathrm{OH}, \mathrm{Molinate}}$ ) is

$$
\begin{aligned}
k_{\mathrm{OH}, \text { Molinate }}^{\prime} & =\text { Slope of Molinate in Figure }(3) \times k_{\mathrm{OH}, \mathrm{NB}} \\
& =k_{\mathrm{OH}, \text { Molinate }}+k_{\mathrm{O}_{3}, \text { Molinate }} / R_{\mathrm{ct}} .
\end{aligned}
$$

A constant slope of molinate $\left(R^{2}>0.99\right)$ indicates that the $R_{c t}$ remains constant as the $\mathrm{O}_{3}$ doses increased from 0.5 to $3 \mathrm{mgL}^{-1}\left(\mathrm{H}_{2} \mathrm{O}_{2} / \mathrm{O}_{3}\right.$ molar ratios from 10 to 1.6$)$ in the $\mathrm{O}_{3} / \mathrm{H}_{2} \mathrm{O}_{2}$ process. Assuming $R_{\mathrm{ct}}=10^{-7}$ (Chen et al., 2006) and $k_{\mathrm{OH} \text {,Molinate }}=6.9 \times 10^{9} \mathrm{M}^{-1} \mathrm{~s}^{-1}$ (Shemer et al., 2006), the esti-

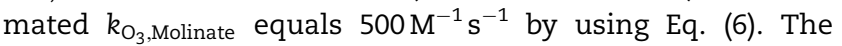
ozone reactivity of EPTC is expected to be comparable to that of molinate because of their similar chemical structures. Both chemicals can be fast degraded by conventional ozonation and by the $\mathrm{OH}$ radical-dominated treatment processes.

\subsection{Nitrotoluenes and nitrobenzene}

The basic direct ozone reaction with aromatic compounds is by electrophilic aromatic substitution reaction because of the stability of the aromatic ring (Beltrán, 2004). Low $k_{\mathrm{O}_{3}, \mathrm{M}}$ values of these chemicals are expected since the strong electronwithdrawing nitro substitutions decrease the electron-density of the aromatic rings and thus lower their $\mathrm{O}_{3}$ reactivity. Beltrán et al. (1998a) found that $k_{\mathrm{O}_{3}, \mathrm{M}}$ value of 2,6-DNT is higher than that of NB due to the electron releasing methyl group that activates the ring during ozone reactions. The $k_{\mathrm{O}_{3}, \mathrm{M}}$ value of NB as measured by Beltrán et al. (1998b) $\left(2.2 \mathrm{M}^{-1} \mathrm{~s}^{-1}\right)$ is more than 20 times higher than that by Hoigné and Bader (1983) $\left(0.09 \mathrm{M}^{-1} \mathrm{~s}^{-1}\right)$. We have previously measured the $k_{\mathrm{O}_{3}, \mathrm{M}}$ of bromobenzene to be $0.16 \mathrm{M}^{-1} \mathrm{~s}^{-1}$ (Chen et al., 2006). Since a nitro group is much more electron-withdrawing than a bromo group, lower $k_{\mathrm{O}_{3}, \mathrm{M}}$ value is expected for nitrobenzene than for bromobenzene. It seems that the $k_{\mathrm{O}, \mathrm{NB}}$ measured by Beltrán et al. (1998b) was overestimated. Because of the strong electron-withdrawing effect of the nitro substituents, $k_{\mathrm{O}_{3}, \mathrm{M}}$ of both 2,4-DNT and 2,6-DNT should be lower than that of toluene (which has no nitro groups, $k_{\mathrm{O}_{3} \text {,toluene }}=14 \pm 3 \mathrm{M}^{-1} \mathrm{~s}^{-1}$ at $23^{\circ} \mathrm{C}$ (Hoigné and Bader, 1983)).

Despite of their low ozone reactivities, all three substituted benzenes are quite reactive toward $\mathrm{OH}$ radicals and thus can be efficiently treated during the $\mathrm{OH}$ radical predominated processes. $k_{\mathrm{OH}, \mathrm{M}}$ of 2,4-DNT is slightly higher than that of its 
isomer 2,6-DNT. The same order is observed in the UV/Fenton system and is attributed to the steric constraints imposed on the methyl group by the 2,6-DNT configuration rather than the 2,4-DNT configuration (Li et al., 1998). The $\mathrm{OH}$ radical attack of the DNTs is usually considered to occur by methyl group oxidation and followed by hydroxylation (Li et al., 1998). This is supported by Beltrán et al. (1998a,b) who found 2,6dinitrobenzaldehyde to be a common product from $\mathrm{OH}$ radical oxidation of 2,6-DNT. However, the $\mathrm{OH}$ radicals react with NB by addition to the ring to form nitrophenols (and other products) (Beltrán et al., 1998a, b); OH radical reaction of NB is faster than that of the DNTs.

\section{Conclusions}

Nine chemicals on the US EPA's Contaminant Candidate List were studied for their reactivity with ozone and $\mathrm{OH}$ radicals during the ozonation and $\mathrm{O}_{3} / \mathrm{H}_{2} \mathrm{O}_{2}$ AOP process. Second-order reaction rate constants with ozone and $\mathrm{OH}$ radicals $\left(k_{\mathrm{O}_{3}, \mathrm{M}}\right.$ and $k_{\mathrm{OH}, \mathrm{M}}$ ) were either measured or estimated from structure/ activity relationships with regard to the reaction mechanisms. The urea herbicides (linuron and diuron), triazine (prometon), RDX and substituted benzene compounds (nitrobenzene, 2,4-dinitrotoluene and 2,6-dinitrotoluene) show low reactivity toward ozone, whereas the thiocarbamates (molinate and EPTC) are highly reactive toward $\mathrm{O}_{3}$ due to the $\mathrm{O}_{3}$ reactive $\mathrm{S}$ atom. All chemicals (except RDX) demonstrate high reactivity toward $\mathrm{OH}$ radicals.

In the water treatment application, only the thiocarbamate herbicides can be efficiently treated by ozonation at low $\mathrm{pH}$, which involves mainly the direct ozone reactions. Ozonation at high $\mathrm{pH}$ and $\mathrm{O}_{3} / \mathrm{H}_{2} \mathrm{O}_{2}$ AOP will be highly efficient for the removal of the thiocarbamates, ureas, prometon and substituted benzenes. However, product studies show that most chemicals are unlikely to be mineralized and the reaction byproducts may be a problem if they are likely to cause health concerns. RDX is more resistant to ozonation and $\mathrm{O}_{3} / \mathrm{H}_{2} \mathrm{O}_{2}$ AOP than any other CCLs in this study.

\section{Acknowledgments}

The US Environmental Protection Agency through its Office of Research and Development funded and collaborated the research described here under CR-829412-01-1 to Duke University and UCLA. It has not been subject to Agency review and therefore does not necessarily reflect the views of the Agency. No official endorsement should be inferred. We thank the reviewers for their helpful comments, Dr. Jiong Chen and Jane Curren for their help in the preparation of this manuscript.

R E F E R E N C E S

Acero, J.L., Stemmler, K., von Gunten, U., 2000. Degradation kinetics of atrazine and its degradation products with ozone and $\mathrm{OH}$ radicals: a predictive tool for drinking water treatment. Environ. Sci. Technol. 34, 591-597.
Armbrust, K.L., 2000. Pesticide hydroxyl radical rate constants: measurements and estimates of their importance in aquatic environments. Toxicol Chem. 19, 2175-2180.

Bader, H., Hoigné, J., 1981. Determination of ozone in water by the indigo method. Water Res. 15, 449-456.

Barletta, B., Bolzacchini, E., Meinardi, S., Orlandi, M., Rindone, B., 2003. The kinetics and the mechanism of the reaction of 2-chloro-4,6-dialkylamino-1,3,5-triazines with ozone. Ozone Sci. Eng. 25 (2), 81-94.

Beltrán, F.J., 2004. Ozone Reaction Kinetics for Water and Wastewater Systems. Lewis Publisher, New York, NY.

Beltrán, F.J., Encinar, J.M., Alonso, M.A., 1998a. Nitroaromatic hydrocarbon ozonation in water: 2 . Combined ozonation with hydrogen peroxide or UV radiation. Ind. Eng. Chem. Res. 37, 32-40.

Beltrán, F.J., Encinar, J.M., Alonso, M.A., 1998b. Nitroaromatic hydrocarbon ozonation in water: 1 . Single ozonation. Ind. Eng. Chem. Res. 37, 25-31.

Borio, G., Gawlik, B.M., Bellobono, I.R., Muntau, H., 1998. Photooxidation of prometryn and prometon in aqueous solution by hydrogen peroxide on photocatalytic membranes immobilsing titanium dioxide. Chemosphere 37 (5), 975-989.

Bose, P., Glaze, W.H., Maddox, D.S., 1998a. Degradation of RDX by various advanced oxidation processes: 1 . Reaction rates. Water Res. 32 (4), 997-1004.

Bose, P., Glaze, W.H., Maddox, D.S., 1998b. Degradation of RDX by various advanced oxidation processes: 2 . Organic by-products. Water Res. 32 (4), 1005-1018.

Buxton, G.V., Greenstock, C.L., Helman, W.P., Ross, A.B., 1988. Critical review of rate constants for reactions of hydrated electrons, hydrogen atoms and hydroxyl radicals in aqueous solution. J. Phys. Chem. Ref. Data 17, 513-886 Internet: < http:// kinetics.nist.gov/solution/index.php $\rangle$ or $\langle$ http://allen.rad. nd.edu $>$.

Chen, W.R., Sharpless, C.M., Linden, K.G., Suffet, I.H., 2006. Treatment of volatile organic chemicals on the EPA contaminant candidate list using ozonation and the $\mathrm{O}_{3} / \mathrm{H}_{2} \mathrm{O}_{2}$ advanced oxidation process. Environ. Sci. Technol. 40 (8), 2734-2739.

De Laat, J., Maouala-Makata, P., Dore, M., 1996. Rate constants for reactions of ozone and hydroxyl radicals with several phenylureas and acetamides. Environ. Technol. 17, 707-716.

Elovitz, M.S., von Gunten, U., 1999. Hydroxyl radical/ozone ratios during ozonation processes. I. The $\mathrm{R}_{\mathrm{ct}}$ concept. Ozone Sci. Eng. 21, 239-260.

Hoigné, J., Bader, H., 1983. Rate constants of reactions of ozone with organic and inorganic compounds in water. I. Nondissociating organic compounds. Water Res. 17, 173-183.

Li, Z.M., Shea, P.J., Comfort, S.D., 1998. Nitrotoluene destruction by UV-catalyzed fenton oxidation. Chemosphere 36 (8), 1849-1865.

Meijers, R.T., Oderwald-Muller, E.J., Nuhn, P.A.N.M., Kruithof, J.C., 1995. Degradation of pesticides by ozonation and advanced oxidation. Ozone Sci. Eng. 17, 673-686.

Nélieu, S., Kerhoas, L., Einhorn, J., 2000. Degradation of atrazine into ammeline by combined ozone/hydrogen peroxide treatment in water. Environ. Sci. Technol. 34, 430-437.

Shemer, H., Sharpless, C.M., Elovitz, M.S., Linden, K.G., 2006. Relative rate constants of contaminant candidate list pesticides with hydroxyl radicals. Environ. Sci. Technol. 40, 4460-4466.

Tahmasseb, A.L., Nélieu, L.S., Kerhoas, L., Einhorn, J., 2002. Ozonation of chlorophenylurea pesticides in water: reaction monitoring and degradation pathways. Sci. Total Environ. 291, 33-44.

US Environmental Protection Agency, 1998. Announcement of the drinking water contaminant candidate list. Fed. Regist. 63 (40), 10273.

Xiong, F., Graham, N.J.D., 1992. Rate constants for herbicides degradation by ozone. Ozone Sci. Eng. 14, 283-301.

Yao, C.C.D., Haag, W.R., 1991. Rate constants for direct reactions of ozone with several drinking water contaminants. Water Res. 25, 761-773. 